\title{
Influence of Geological Factor on Indoor Radon Concentrations in Dwelling of Querétaro, México
}

\author{
Rocio García Martínez ${ }^{1}$, Anatoliy Kotsarenko², Roman Pérez Enriquez ${ }^{3}$, \\ Jose Antonio López Cruz Abeyro ${ }^{3}$, Svetlana Koshevaya4, Jesús Efrén Ospina Noreña ${ }^{5}$ \\ ${ }^{1}$ Centro de Ciencias de la Atmósfera, Universidad Nacional Autónoma de México, Ciudad Universitaria, \\ México City, México \\ ${ }^{2}$ Universidad Autónoma del Carmen (UNACAR), Facultad de Ingeniería, Ciudad del Carmen, México \\ ${ }^{3}$ Centro de Geociencias, Universidad Nacional Autónoma de México, Campus Juriquilla, Querétaro, México \\ ${ }^{4}$ CIICAp, Autonomous University of State Morelos (UAEM), Cuernavaca, México \\ ${ }^{5}$ Programa de Investigación de Cambio Climático, Universidad Nacional Autónoma de México, Ciudad \\ Universitaria, México City, México \\ Email: "gmrocio@atmosfera.unam.mx
}

Received 21 September 2014; revised 18 October 2014; accepted 15 November 2014

Copyright (C) 2014 by authors and Scientific Research Publishing Inc.

This work is licensed under the Creative Commons Attribution International License (CC BY).

http://creativecommons.org/licenses/by/4.0/

(c) (i) Open Access

\section{Abstract}

In this study, radon-222 concentrations were measured within 34 houses distributed in the northern, southern, and central areas of the city of Querétaro in 2007. The objective of this study was to establish the spatial distribution of radon with respect to geological faults and its relation to certain environmental variables. For each sampling site, the radon-222 concentration was analyzed as a function of various climate variables, relative humidity, temperature, and atmospheric pressure, in addition to the ventilation of the house and distance of each site from any geological faults in the area. A multivariate statistical technique was used to analyze these variables based on two components. For component 1 , the relative humidity and temperature had the greatest weight, 0.677 and 0.492 , respectively, while for component 2 , the greatest weights corresponded to radon and the temperature with 0.693 and 0.609 , respectively. The average radon concentration across the entire sampling period was $38.92 \mathrm{~Bq} / \mathrm{m}^{3}$, the minimum detected value was $6.01 \mathrm{~Bq} / \mathrm{m}^{3}$ for site 91GAG0607, and the maximum detected value was $225.95 \mathrm{~Bq} / \mathrm{m}^{3}$ for site $91 \mathrm{CAM} 20907$. This last value is outside the standards permitted by the Environmental Protection Agency of the United Stated, which is $148 \mathrm{~Bq} / \mathrm{m}^{3}$ for indoor environments. With respect to geological faults and their relationship to radon-222, the concentrations for the sampling sites had no relationship to the closeness or distance to these faults.

\footnotetext{
*Corresponding author.
}

How to cite this paper: Martínez, R.G., Kotsarenko, A., Enriquez, R.P., Cruz Abeyro, J.A.L., Koshevaya, S. and Noreña, J.S.O. (2014) Influence of Geological Factor on Indoor Radon Concentrations in Dwelling of Querétaro, México. Open Journal of Geology, 4, 627-635. http://dx.doi.org/10.4236/ojg.2014.412047 
Keywords

Indoor Radon, Geology, Building Characteristics and Seasonal Variations

\section{Introduction}

Radon is a gaseous, colorless, and tasteless element. It is chemically inert and has several isotopes, but the most important is radon-222 with a half-life of 3.8 days. This atom is the direct product of the decay of radon-226, which is produced in turn by the decay of uranium-238. The particularity of elemental radon is that it is a gas naturally emitted at geological faults, which makes it hazardous to health. Radon is present in outdoor environments in low concentrations. However, in indoor environments, radon can accumulate until it poses a potential long-term health risk. Given the solubility of radon in air and its abundance, the U.S. Environmental Protection Agency (EPA) defines $4 \mathrm{pCi} / \mathrm{L}$, which equals $148 \mathrm{~Bq} / \mathrm{m}^{3}$, as the maximum allowed radon concentration in homes [1]. Most of the natural radioactivity human beings are exposed to be due to radon [2]. This element is capable of traveling through pores in the ground until it reaches the surface, where it is diluted with other atmospheric gases or penetrates into buildings that are not appropriately protected. In both cases, its decay process is completed. After penetrating a closed space, radon accumulates and increases in concentration. It is possible that problems related to high levels of radon in indoor environments could be more common in certain geographical regions due to their topography and orography.

The state of Querétaro is bordered by volcanoes and regional faults that affect the area and are grouped into two primary, active systems [3]-[5]. These faults are consistent in both direction and kinematics with the two regional fault systems (with north-south and east-west orientations). Because of this, the local geological structures of the state and its environmental impact have been independently studied [5] [6]. Distributed along the two large geological faults crossing the state (Tlacote and 5 de Febrero) are three urban centers important to the state of Querétaro (Juriquilla, Jurica, and the City Center). Juriquilla is located in the northern part of the state at the exit of the Querétaro-San Luis Potosí highway and is surrounded by large residential complexes with dense commercial activity and large university campuses. Jurica, located $15 \mathrm{~km}$ from the center of the state, is surrounded by ranches, residential zones, and small areas dedicated to local agriculture. The capital city, an area with dense commercial and tourist activity, is surrounded by streets with intense vehicle traffic.

Based on the above, this study proposed to determine the spatial distribution of radon with respect to geological faults and its relationship to certain environmental variables. The concentration of radon was determined in 34 residences in 2007 across two periods, March-June and September-November, which correspond to the dry-hot and wet periods, respectively. Figure 1 shows the distribution of the sampling sites in each of the selected areas (Juriquilla, Jurica, and City Center, Querétaro).

\section{Methodology}

\subsection{Sampling Sites}

Because of the interest in the behavior of radon gas in indoor environments, this study samples houses in the city of Queretaro due to their aforementioned geological history and the ability are provided to evaluate the air quality that inhabitants are most likely exposed to, especially housewives and children who spend most of their time in these environments with the latter being the most vulnerable. The initial idea was to monitor houses with similar construction characteristics, and typical problems encountered were owners' availability and the complex architecture of houses in the study areas.

\subsection{Sampling}

Sampling was performed using an SARAD Radon Scout instrument. Its design and memory size allowed for real-time measurements with high accuracy. This instrument can exactly determine variations in radon-222, even at low concentrations. The instrument consists of sensors that measure the humidity, temperature, and barometric pressure using the SARAD GmbH software, version 5.0. The measurement periods varied from 7 to 15 days, and the integration time was one hour (one sample per hour) for all of the measurements. 




Figure 1. Location of the 34 homes sampled in Juriquilla room, Jurica and the Center Querétaro, México.

\section{Results}

Table 1 presents the maximum (max), average (avg), minimum (min) values of the measured variables and the geographical coordinates of the sampled sites. Any sites with an average radon concentration above $148 \mathrm{~Bq} / \mathrm{m}^{3}$, which is the highest level recommended by the U.S. EPA, are highlighted in black.

\subsection{Statistical Analysis}

Using the obtained results, a Spearman's rank correlation analysis was performed to determine whether any statistically significant linear correlations existed with a confidence level of $95 \%$ among the analyzed variables. According to the analysis, no linear correlations existed (See Annex A). However, this does not necessarily imply that the variables are independent because they could be non-linearly related.

\subsection{Cluster Analysis (CA)}

The following variables were observed at each site: temperature $\left({ }^{\circ} \mathrm{C}\right)$, relative humidity $(\%)$, atmospheric pressure, and radon concentration. Additionally, a multivariate statistical analysis was performed. A cluster analysis (CA) was applied by forming 3 groups: group 1 is comprised of 12 residences located in the central zone and 
Table 1. The maximum (max), average (avg), and minimum (min) values of radon-222 (bq/ $\mathrm{m}^{3}$ ) concentration; temperature $\left({ }^{\circ} \mathrm{C}\right)$; relative humidity (\%); atmospheric pressure; and geographical coordinates at the sampled sites.

\begin{tabular}{|c|c|c|c|c|c|c|c|}
\hline Site & Reference & $\begin{array}{c}\text { Radon } \\
\left(\mathrm{Bq} / \mathrm{m}^{3}\right)\end{array}$ & Temperature $\left({ }^{\circ} \mathrm{C}\right)$ & $\begin{array}{c}\text { Relative } \\
\text { Humidity (\%) }\end{array}$ & Pressure & Latitude & Longitud \\
\hline 1 & 149FER1207 & 14.63 & 16.85 & 54.83 & 821.11 & 20.5816 & -100.3780 \\
\hline 2 & 148TER1107 & 17.54 & 19.04 & 48.97 & 820.44 & 20.5976 & -100.3906 \\
\hline 3 & 92RPE21107 & 32.07 & 18.34 & 52.61 & 820.52 & 20.5363 & -100.4226 \\
\hline 4 & 91JUR10307 & 11.69 & 21.76 & 37.24 & 806.37 & 20.7020 & -100.4471 \\
\hline 5 & 92JUR20307 & 44.46 & 19.97 & 40.20 & 808.95 & 20.7025 & -100.4467 \\
\hline 6 & 90JUR0307 & 21.17 & 19.53 & 43.54 & 806.94 & 20.7020 & -100.4476 \\
\hline 7 & 92LCA0407 & 22.85 & 21.18 & 32.75 & 806.40 & 20.7227 & -100.4412 \\
\hline 8 & 90FRZ0407 & 45.57 & 24.88 & 34.46 & 811.42 & 20.7111 & -100.4588 \\
\hline 9 & 91RPE0407 & 13.90 & 22.57 & 34.38 & 817.53 & 20.5364 & -100.4227 \\
\hline 10 & 90DIL0507 & 13.51 & 24.46 & 38.61 & 819.39 & 20.5889 & -100.4319 \\
\hline 11 & 90ROD0507 & 31.84 & 27.00 & 33.02 & 808.54 & 20.6557 & -100.3940 \\
\hline 12 & 91CAM10507 & 192.43 & 24.69 & 48.74 & 819.99 & 20.6595 & -100.4475 \\
\hline 13 & 90VAS0607 & 34.86 & 27.04 & 37.90 & 819.22 & 20.6574 & -100.4428 \\
\hline 14 & 92JAR0607 & 20.75 & 22.59 & 43.12 & 810.06 & 20.7022 & -100.4538 \\
\hline 15 & 91GAG0607 & 6.01 & 24.01 & 38.69 & 811.61 & 20.5714 & -100.3807 \\
\hline 16 & 92GEO0607 & 31.08 & 21.24 & 54.64 & 822.00 & 20.6483 & -100.4433 \\
\hline 17 & 91ANS0607 & 18.10 & 22.73 & 55.13 & 809.92 & 20.6396 & -100.4042 \\
\hline 18 & 90JML0607 & 9.63 & 19.48 & 70.76 & 811.27 & 20.6344 & -100.4762 \\
\hline 19 & 91MPE0707 & 16.85 & 22.44 & 59.74 & 813.39 & 20.6340 & -100.4761 \\
\hline 20 & 92LIL0707 & 12.93 & 22.72 & 57.56 & 822.77 & 20.5827 & -100.3918 \\
\hline 21 & 90МСH0707 & 11.41 & 22.65 & 60.82 & 810.72 & 20.7109 & -100.4545 \\
\hline 22 & 91САМ20907 & 225.95 & 22.00 & 64.99 & 819.61 & 20.6595 & -100.4475 \\
\hline 23 & 92САМ30907 & 27.70 & 20.78 & 66.93 & 821.18 & 20.6595 & -100.4475 \\
\hline 24 & 91MAR1007 & 19.23 & 22.22 & 56.04 & 819.77 & 20.6542 & -100.4381 \\
\hline 25 & 92HAR1007 & 10.51 & 21.19 & 54.08 & 811.49 & 20.7088 & -100.4562 \\
\hline 26 & 147DOR1007 & 9.10 & 20.91 & 56.68 & 814.86 & 20.6603 & -100.4222 \\
\hline 27 & 92GIL1007 & 79.62 & 21.40 & 55.43 & 817.44 & 20.5950 & -100.3890 \\
\hline 28 & 149ALX1107 & 163.18 & 19.12 & 55.26 & 812.48 & 20.6493 & -100.4470 \\
\hline 29 & 91MAN1007 & 22.45 & 20.74 & 57.39 & 804.29 & 20.7158 & -100.4462 \\
\hline 30 & 148SUM1007 & 16.67 & 20.30 & 50.94 & 817.93 & 20.5636 & -100.4160 \\
\hline 31 & 90JUV11007 & 57.76 & 24.07 & 47.33 & 817.03 & 20.6247 & -100.5020 \\
\hline 32 & 147REF1007 & 41.67 & 20.97 & 51.40 & 821.06 & 20.5443 & -100.4190 \\
\hline 33 & 91ANT1107 & 13.18 & 18.37 & 47.74 & 809.29 & 20.7166 & -100.4426 \\
\hline \multirow[t]{4}{*}{34} & 147CRL1107 & 13.07 & 19.30 & 40.84 & 824.92 & 20.5745 & -100.4137 \\
\hline & MAX & 225.95 & 27.0 & 70.8 & 824.9 & & \\
\hline & MED & 38.92 & 21.7 & 49.5 & 815.0 & & \\
\hline & MIN & 6.01 & 16.9 & 32.8 & 804.3 & & \\
\hline
\end{tabular}


corresponds to 35\% of the total of sampled houses; group 2 is comprised of 19 residences and corresponds to $56 \%$ of the samples; group 3 is comprised of $9 \%$ of the samples. In this last group, sites 12, 22, and 28 differ from the other sampled sites because they had radon concentrations above the norms permitted by the U.S. EPA (148 $\mathrm{Bq} / \mathrm{m}^{3}$ ) for indoor environments (Table 2). In Figure 2, the distribution of the sites with respect to their grouping is presented. It is worth noting that the distribution of houses at each site depended upon the availability and help from the proprietor of the house. Although a similar number of samplings were planned for each site, this goal was not possible. The aforementioned groups differ in their variables as shown in Table 3, and one can observe the centroids of each variable in each group. This analysis indicates group 3 is influenced by humidity.

Table 2. Formation of 3 groups, cluster analysis.

\begin{tabular}{|c|c|c|}
\hline Cluster & $\mathbf{N}^{\circ}$ Dendrogram & Site \\
\hline \multirow{12}{*}{1} & 1 & 149FER1207 \\
\hline & 2 & 148TER1107 \\
\hline & 3 & 92RPE21107 \\
\hline & 16 & 92GEO0607 \\
\hline & 20 & 92LIL0707 \\
\hline & 23 & 92САМ30907 \\
\hline & 24 & 91MAR1007 \\
\hline & 27 & 92GIL1007 \\
\hline & 30 & 148SUM1007 \\
\hline & 31 & 90JUV11007 \\
\hline & 32 & 147REF1007 \\
\hline & 34 & 147CRL1107 \\
\hline \multirow{19}{*}{2} & 4 & 91JUR10307 \\
\hline & 5 & 92JUR20307 \\
\hline & 6 & 90JUR0307 \\
\hline & 7 & 92LCA0407 \\
\hline & 8 & 90FRZ0407 \\
\hline & 9 & 91RPE0407 \\
\hline & 10 & 90DIL0507 \\
\hline & 11 & 90ROD0507 \\
\hline & 13 & 90VAS0607 \\
\hline & 14 & 92JAR0607 \\
\hline & 15 & 91GAG0607 \\
\hline & 17 & 91ANS0607 \\
\hline & 18 & 90JML0607 \\
\hline & 19 & 91MPE0707 \\
\hline & 21 & 90MCH0707 \\
\hline & 25 & 92HAR1007 \\
\hline & 26 & 147DOR1007 \\
\hline & 29 & 91MAN1007 \\
\hline & 33 & 91ANT1107 \\
\hline \multirow{3}{*}{3} & 12 & 91CAM10507 \\
\hline & 22 & 91CAM20907 \\
\hline & 28 & 149ALX1107 \\
\hline
\end{tabular}


Table 3. Centroids for each variable radon-222 $\left(\mathrm{Bq} / \mathrm{m}^{3}\right)$ concentration; temperature $\left({ }^{\circ} \mathrm{C}\right)$; relative humidity $(\%)$; atmospheric pressure.

\begin{tabular}{ccccc}
\hline Cluster & Radon $\left(\mathbf{B q} / \mathbf{m}^{\mathbf{3}}\right)$ & Temperature $\left({ }^{\circ} \mathbf{C}\right)$ & Relative Humidity $(\%)$ & Atmospheric Pressure \\
\hline 1 & 30.33 & 20.60 & 53.12 & 820.51 \\
2 & 19.88 & 22.28 & 46.11 & 811.14 \\
3 & 193.85 & 21.93 & 56.33 & 817.36 \\
\hline
\end{tabular}

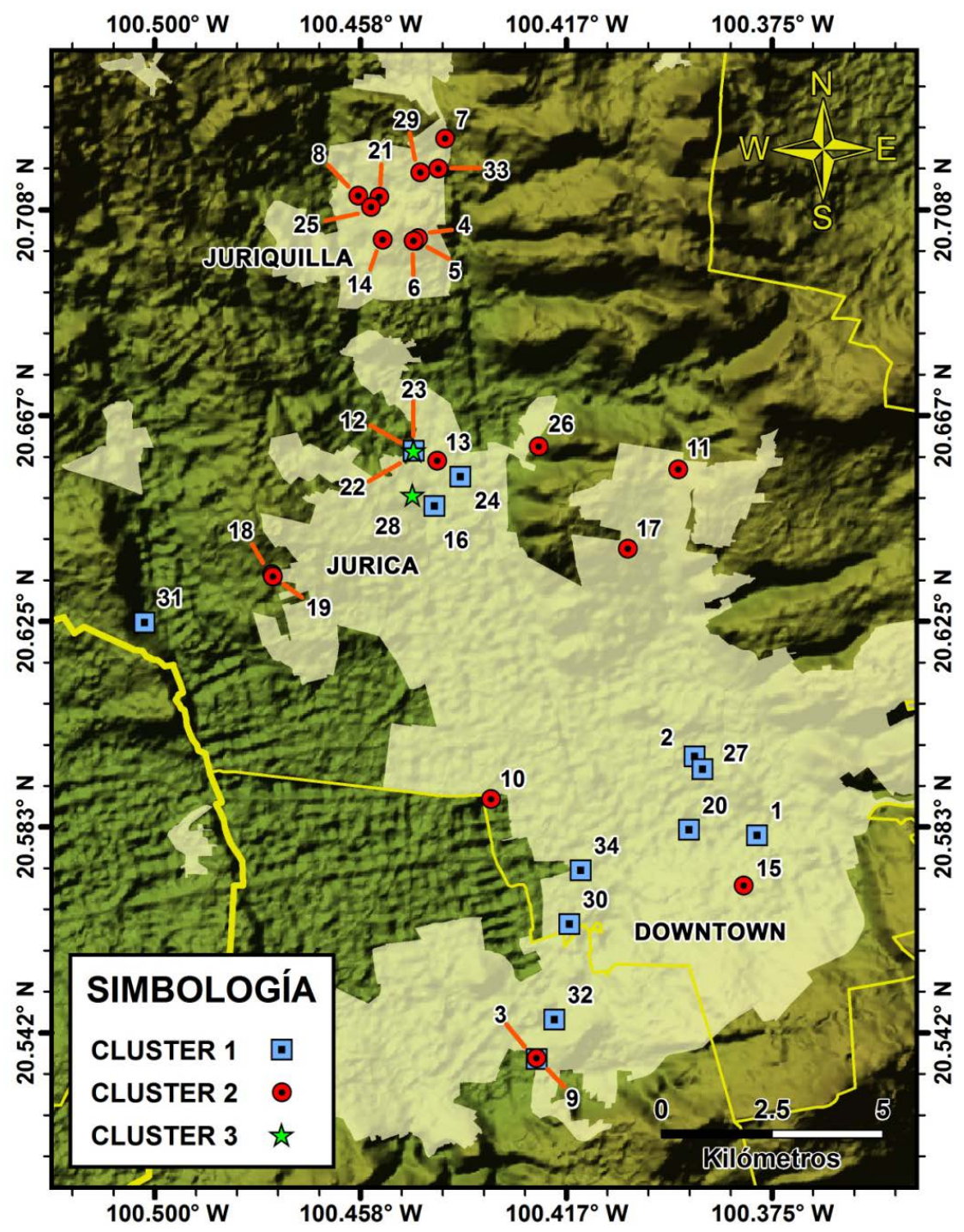

Figure 2. Geographic location of the sites with respect to formation of Cluster Analysis.

\subsection{Principal Component Analysis (PCA)}

A principal component analysis or factor analysis was performed to determine the associations between the analyzed variables and estimate the possible origins of the radon concentrations in the indoor environments of the 34 sampled houses [7] [8]. The first two components of this principal component analysis that obtained an eigenvalue above 1 were extracted and represent $67.29 \%$ of the variability in the observed data (Table 4), which is assumed sufficient for the analysis performed here.

Table 5 presents the weights for each component variable. In it, one can observe that for component 1, rela- 
Table 4. Principal Component Analysis (PCA).

\begin{tabular}{cccc}
\hline Component Number & Eigenvalue & Percent of Variance & Cumulative Percentage \\
\hline 1 & 1.530 & 38.267 & 38.267 \\
2 & 1.161 & 29.032 & 67.299 \\
3 & 0.801 & 20.032 & 87.331 \\
4 & 0.506 & 12.669 & 100.000 \\
\hline
\end{tabular}

Table 5. Weights for each component variable.

\begin{tabular}{ccc}
\hline Variable & Component 1 & Component 2 \\
\hline Relative humidity & 0.677 & -0.111 \\
Atmospheric pressure & 0.460 & 0.369 \\
Radon & 0.294 & 0.693 \\
Temperature & -0.491 & 0.608 \\
\hline
\end{tabular}

tive humidity and temperature have the highest weights, 0.677 and 0.492 , respectively; while the greatest weights for component 2 correspond to radon and temperature with values of 0.693 and 0.609 , respectively. Using the obtained radon concentrations, we attempted to establish the spatial distribution of radon with respect to the geological faults. However, there was no evidence that the location of the houses and the faults were directly related, which was verified by the PCA results.

\subsection{Factor Analysis (FA)}

The purpose of the FA was to strengthen the PCA results and obtain a number of factors to explain most of the variability in the three meteorological variables measured (relative humidity, temperature, and atmospheric pressure) across two periods, March-June and September-November, which correspond to the dry-hot and wet periods, respectively. The relative humidity and temperature that exist within the houses determined the flow of radon towards the interior.

In the PCA, two factors were found to represent $67.29 \%$ of the variability in the original data (Table 4). The FA corroborates what was observed in the PCA and shows that the relative humidity and temperature have the greatest weights for factor 1 with values of -0.747 and 0.878 , respectively, while the greatest weights for factor 2 correspond to radon and the pressure with values of 0.818 and 0.657 , respectively (Table 6). These findings allow us to infer that component 1 , or factor 1 , is influenced by environmental conditions relating to the humidity and temperature because some periods of the year could be cold dry, cold wet, hot dry, or hot wet for example.

In contrast, component 2, or factor 2, favors certain mixing conditions or the presence of certain substances in the air. For these reasons, it is important to consider how wind acts on the indoor radon concentration in two opposing manners. On the one hand, the wind can favor the exchange of air between the interior and exterior of a dwelling depending on its architectural characteristics. On the other hand, the wind induces a local pressure difference between the interior and exterior, which favors the entry of radon into closed sites. These atmospheric variables do not affect the air of houses in the same way and a phase difference occurs over time until the conditions equilibrate.

\section{Conclusions}

The results obtained for the concentration of radon-222 in the 34 sampled residences did not show a relationship to the distance of the residence from the geological faults in the region. In addition, the radon-222 concentration and its relationship to the studied meteorological variables (relative humidity, temperature, and atmospheric pressure) were independent of the sampling periods, March-June and September-November, which correspond to the dry-hot and wet periods, respectively. Using the obtained data, statistical tests of the linear region were performed to determine whether seasonal variations in the radon-222 concentration existed. However, convincing results that would permit us to explain the variation were not obtained. If one rules out faults as a cause of 
Table 6. Factor matrix after rotation varimax.

\begin{tabular}{ccc}
\hline Variable & Factor 1 & Factor 2 \\
\hline Relative humidity & -0.747 & 0.397 \\
Atmospheric pressure & -0.225 & 0.657 \\
Radon & 0.146 & 0.818 \\
Temperature & 0.878 & 0.170 \\
\hline
\end{tabular}

the radon-222 distribution in dwellings, then it is probable that the data obtained obey other factors, such as the construction material or ventilation conditions of each home, which were not considered in this study.

This work, together with that of [9]-[11], helps provide an explanation or cause for the radon-222 concentrations in dwellings. Future studies must account for a greater number of variables and residences and include simultaneous sampling of both indoor and outdoor environments to better reflect reality when explaining what occurs in dwellings in the state of Querétaro.

\section{Acknowledgements}

We would like to thank Jorge Juan Manuel Lopez, Emilio Nava, Saul Armendariz and UNIATMOS for their technical assistance and Claudio Amescua for his writing assistance. This study was partially supported by Dirección General de Asuntos Académicos, Universidad Nacional Autónoma de México, Projects PAPIIT IN114806 and PAPIIT IN120808.

\section{References}

[1] Canoba, A., López, F.O., Arnaud, M.I., Oliveira, A.A., Neman, R.S., Hadler, J.C., Iounes, P.J., Paulo, S.R., Osorio, A.M., Aparicio, R., Rodríguez, C., Moreno, V.,Vasquez, R., Espinosa, G., Golzarri, J.I., Martínez, T., Navarrete, M., Cabrera, I., Segovia, N., Peña, P., Taméz, E., Pereyra, P., López-Herrera, M.E. and Sajo-Bohus, L. (2002) Indoor Radon Measurements in Six Latin American Countries, 2002. Geofisica Internacional, 41, 453-457.

[2] Cothern, C.R. and Smith Jr., J.E. (1987) Environmental Radon. Springer, New York.

[3] Aguirre-Díaz, G.J., Zúñiga Dávila Madrid, R., Pacheco Alvarado, F.J., Guzmán Speziale, M. and Nieto Obregón, J. (2000) El graben de Querétaro, Querétaro, México. Observaciones de fallamiento activo. Geos, boletín de la Unión Geofísica Mexicana, 20, 2-7.

[4] Aguirre-Díaz, G.J. and López-Martínez, M. (2001) The Amazcala Caldera, Querétaro, Central Mexican Volcanic Belt, México. Geology and Geochronology. Journal of Volcanology and Geothermal Research, 111, 203-218. http://dx.doi.org/10.1016/S0377-0273(01)00227-X

[5] Alaniz-Álvarez, S.A., Nieto-Samaniego, A.F., Orozco-Esquivel, M.T., Vasallo-Morales, L.F. and Xu, S.S. (2002) El sistema de fallas Taxco-San Miguel de Allende; implicaciones en la deformación post-eocénica del centro de México. Boletín de la Sociedad Geológica Mexicana, 55, 12-29.

[6] Godínez, R. and Juandiego, J. (2000) Normatividad Federal y Programas sectoriales aplicables al Ordenamiento Ecológico General del Territorio. Primer Congreso Nacional de Ordenamiento del Territorio, Guadalajara (México), 2000, 369-386.

[7] Shrestha, S. and Kazama, F. (2007) Assessment of Surface Water Quality Using Multivariate Statistical Techniques: A Case Study of the Fuji River Basin, Japan. Environmental Modelling \& Software, 22, 464-475. http://dx.doi.org/10.1016/j.envsoft.2006.02.001

[8] Helena, B., Pardo, R., Vega, M., Barrado, E., Fernández, J.M. and Fernández, L. (2000) Temporal Evolution of Groundwater Composition in an Alluvial Aquifer (Pisuerga River, Spain) by Principal Component Analysis. Water Research, 34, 807-816. http://dx.doi.org/10.1016/S0043-1354(99)00225-0

[9] Espinosa, G. and Gammage, R.B. (1998) Indoor Radon Concentration Survey in Mexico. Journal of Radioanalytical and Nuclear Chemistry, 236, 227-229. http://dx.doi.org/10.1007/BF02386347

[10] Espinosa, G. and Gammage, R.B. (1999) Radon Distribution inside Dwellings in Mexico. Radiation Protection Dosimetry, 85, 325-328. http://dx.doi.org/10.1093/oxfordjournals.rpd.a032863

[11] Espinosa, G., Golzarri, J.I. Rickards, R. and Gammage, R.B. (1999) Distribution of Indoor Radon Levels in Mexico. Radiation Measurements, 31, 355-358. http://dx.doi.org/10.1016/S1350-4487(99)00171-7 
Supplementary Data

Annex A (Spearman Rank Correlations)

spearman Rank Correlations

\begin{tabular}{|c|c|c|c|}
\hline & Hum_Rel & Pres & Radon \\
\hline Hum_Rel & & $\begin{array}{r}0.2718 \\
(\quad 34) \\
0.1184\end{array}$ & $\begin{array}{r}-0.0769 \\
(\quad 34) \\
0.6589\end{array}$ \\
\hline Pres & $\begin{array}{r}0.2718 \\
\left(\begin{array}{r}34) \\
0.1184\end{array}\right.\end{array}$ & & $\begin{array}{r}0.0998 \\
\left(\begin{array}{r}34) \\
0.5665\end{array}\right.\end{array}$ \\
\hline Radon & $\begin{array}{r}-0.0769 \\
\left(\begin{array}{r}34) \\
0.6589\end{array}\right.\end{array}$ & $\begin{array}{r}0.0998 \\
\left(\begin{array}{r}34) \\
0.5665\end{array}\right.\end{array}$ & \\
\hline Temp & $\begin{array}{r}-0.2856 \\
\left(\begin{array}{r}34) \\
0.1009\end{array}\right.\end{array}$ & $\begin{array}{r}-0.0900 \\
(\quad 34) \\
0.6052\end{array}$ & $\begin{array}{r}0.1294 \\
(\quad 34) \\
0.4572\end{array}$ \\
\hline
\end{tabular}

Correlation

(Sample Size)

P-Value 
Scientific Research Publishing (SCIRP) is one of the largest Open Access journal publishers. It is currently publishing more than 200 open access, online, peer-reviewed journals covering a wide range of academic disciplines. SCIRP serves the worldwide academic communities and contributes to the progress and application of science with its publication.

Other selected journals from SCIRP are listed as below. Submit your manuscript to us via either submit@scirp.org or Online Submission Portal.
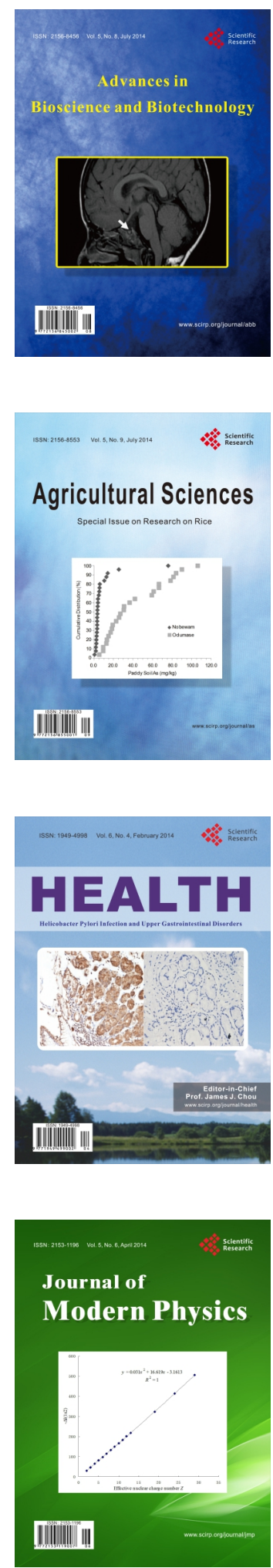
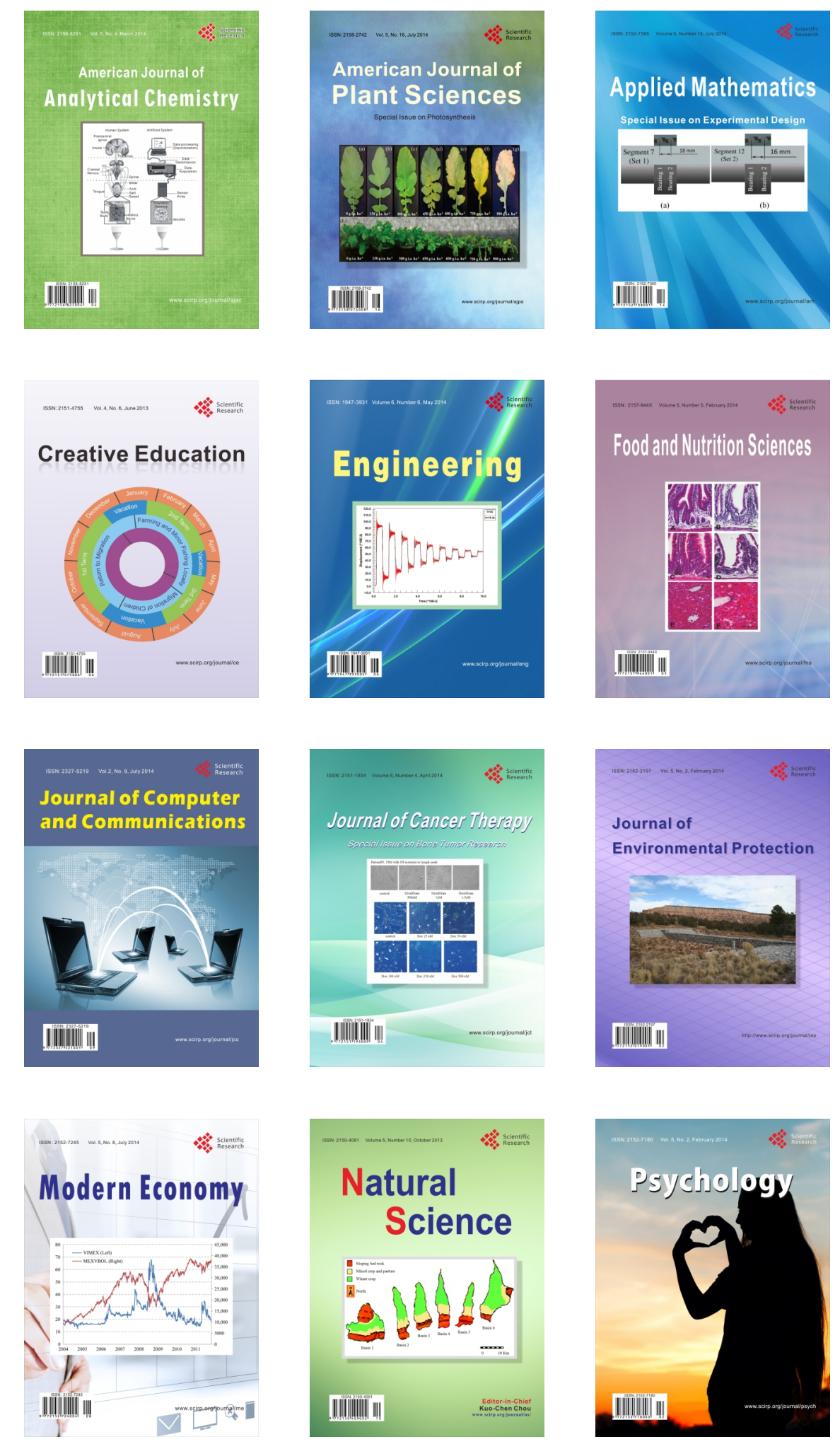